\title{
Coil-On-Plug Ignition for Oxygen/Methane Liquid Rocket Engines in Thermal-Vacuum Environments
}

\author{
John C. Melcher ${ }^{1}$, Matthew J. Atwell ${ }^{2}$, Robert L. Morehead ${ }^{3}$, Eric A. Hurlbert ${ }^{4}$ \\ NASA Johnson Space Center, Houston, TX, 77058, United States \\ and \\ Luz Bugarin ${ }^{5}$, Mariana Chaidez ${ }^{6}$ \\ The University of Texas at El Paso, El Paso, TX, 79968, United States
}

\begin{abstract}
A coil-on-plug ignition system has been developed and tested for Liquid Oxygen (LOX)/liquid methane $\left(\mathrm{LCH}_{4}\right)$ rocket engines operating in thermal vacuum conditions. The igniters were developed and tested as part of the Integrated Cryogenic Propulsion Test Article (ICPTA), previously tested as part of the Project Morpheus test vehicle. The ICPTA uses an integrated, pressure-fed, cryogenic LOX/LCH4 propulsion system including a reaction control system (RCS) and a main engine. The ICPTA was tested at NASA Glenn Research Center's Plum Brook Station in the Spacecraft Propulsion Research Facility (B-2) under vacuum and thermal vacuum conditions. A coil-on-plug ignition system has been developed to successfully demonstrate ignition reliability at these conditions while preventing corona discharge issues. The ICPTA uses spark plug ignition for both the main engine igniter and the RCS. The coil-on-plug configuration eliminates the conventional high-voltage spark plug cable by combining the coil and the spark plug into a single component. Prior to ICPTA testing at Plum Brook, component-level reaction control engine (RCE) and main engine igniter testing was conducted at NASA Johnson Space Center (JSC), which demonstrated successful hot-fire ignition using the coil-on-plug from sea-level ambient conditions down to $10^{-2}$ torr. Integrated vehicle hot-fire testing at JSC demonstrated electrical and command/data system performance. Lastly, hot-fire testing at Plum Brook demonstrated successful ignitions at simulated altitude conditions at 30 torr and cold thermal-vacuum conditions at 6 torr. The test campaign successfully proved that coilon-plug technology will enable integrated LOX/LCH4 propulsion systems in future spacecraft.
\end{abstract}

\section{Nomenclature}

$\begin{array}{ll}A P U & =\text { Avionics and Power Unit } \\ C O P & =\text { Coil on Plug } \\ E M I & =\text { Electro-Magnetic Interference } \\ I C P T A & =\text { Integrated Cryogenic Propulsion Test Article } \\ G R C & =\text { Glenn Research Center } \\ J S C & =\text { Johnson Space Center } \\ \text { LCH4 } & =\text { Liquid Methane } \\ \text { LOX } & =\text { Liquid Oxygen } \\ M I B & =\text { Minimum Impulse Bit } \\ M S F C & =\text { Marshall Space Flight Center }\end{array}$

\footnotetext{
${ }^{1}$ Propulsion System Engineer, Propulsion Systems Branch EP4, AIAA Senior Member

${ }^{2}$ Propulsion System Engineer, Propulsion Systems Branch EP4, AIAA Member

${ }^{3}$ Propulsion System Engineer, Propulsion Systems Branch EP4, AIAA Member

${ }^{4}$ Propulsion System Engineer, Propulsion Systems Branch EP4, AIAA Member

${ }^{5}$ Graduate Research Assistant, Center for Space Exploration and Technology Research, AIAA Student Member

${ }^{6}$ Graduate Research Assistant, Center for Space Exploration and Technology Research
} 
$P C A D=$ Propulsion and Cryogenics Advanced Development

$R C E \quad=$ Reaction Control Engine

RCS $\quad=$ Reaction Control System

$T T L=$ Transistor-Transistor Logic

WSTF = White Sands Test Facility

\section{Introduction}

$\mathrm{M}$

ANY Liquid Oxygen (LOX)/liquid methane $\left(\mathrm{LCH}_{4}\right)$ liquid rocket engine test projects have utilized sparkignition devices for both main engine and reaction control engines. Spark-ignition devices have proven to be a highly reliable technique for LOX/LCH4 ignition for both main engines and RCS, including vacuum testing. For example, NASA previously tested spark-ignition systems for LOX/LCH4 engines during the Propulsion and Cryogenics Advanced Development (PCAD) project ${ }^{1}$ and also during subsequent integrated test projects (e.g., Project Morpheus ${ }^{2}$ ). Some test issues have arisen during different test projects on the spark plug approach, including spark plug durability (e.g., ceramic cracking) and corona discharge during simulated altitude testing. These issues have continued to be improved upon in subsequent test projects.

The NASA Johnson Space Center (JSC) Integrated Cryogenic Propulsion Test Article (ICPTA), shown in Fig. 1, evolved from the existing JSC Project Morpheus hardware and was modified for thermal-vacuum environment testing. One challenge of testing integrated LOX/LCH4 propulsion systems in simulated altitude conditions is the increased risk of corona discharge in spark ignition systems. For ICPTA testing, a coil-on-plug spark ignition system successfully mitigated corona losses during integrated hot-fire demonstrations.

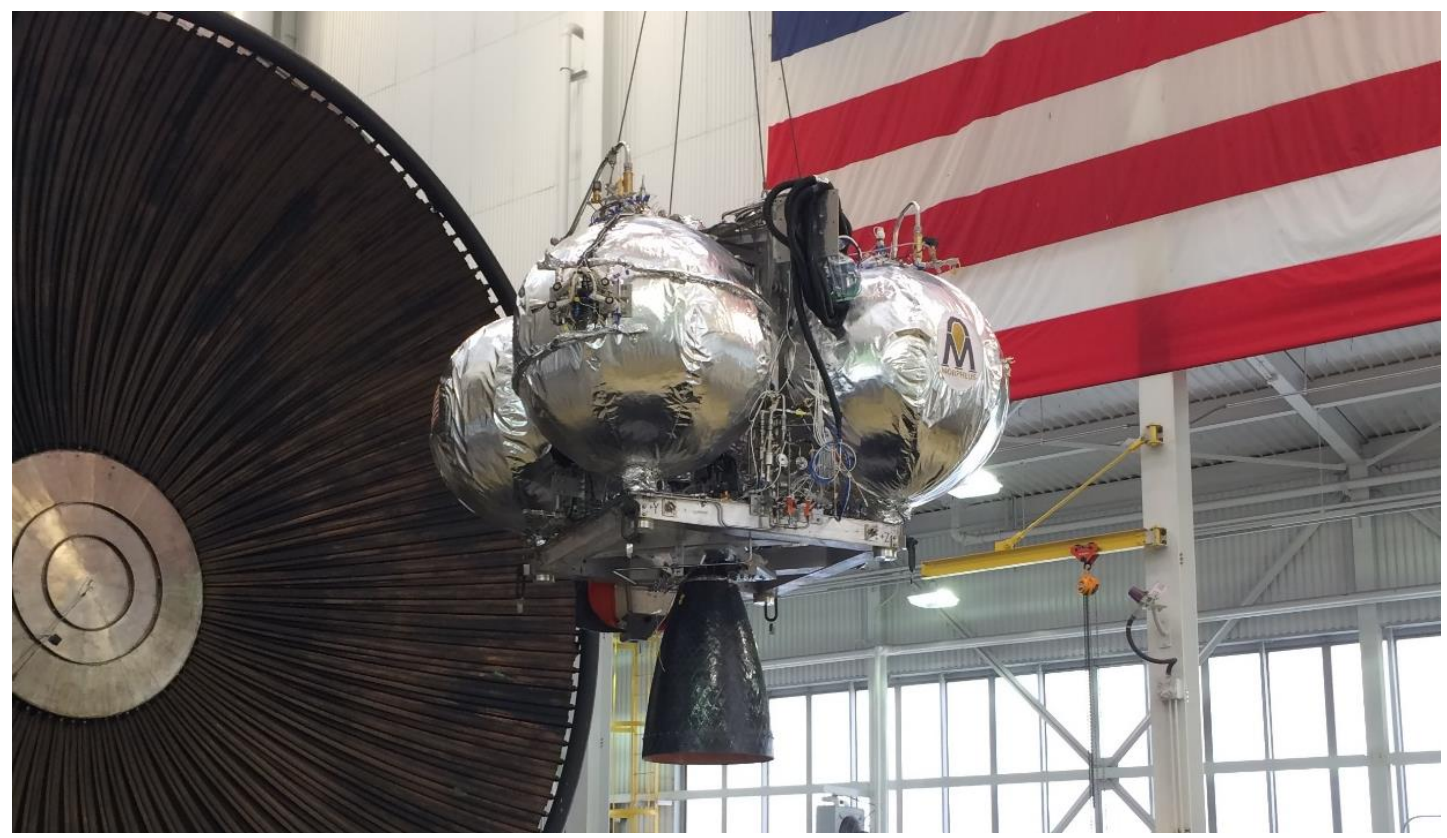

Figure 1. NASA JSC Integrated Cryogenic Propulsion Systems Test Article (ICPTA) at NASA Glenn Research Center (GRC) Plum Brook Station.

\section{A. Problem Statement, Vehicle Integration Architecture}

Corona discharge in reduced-altitude environments is an electrical breakdown in high-voltage components that causes loss of electrical energy to the environment, potential damage to surrounding components, and ultimately a reduced voltage at the intended spark location. The corona discharge is typically evident by luminous discharge (Fig. 2a) and a drop in measured power. The range of concern for corona discharge is described by Paschen's curve, which typically shows the minimum breakdown voltage required across different spark gap distances at various ambient pressures and gas compositions (notionally shown in Fig. 2b). The lowest breakdown voltages are typically in the 1 to 10 torr-cm range, depending on the gas, which indicates corona discharge can be a significant problem for 
propulsion systems testing at altitude conditions or in a Mars environment condition ( 4.5 torr, $\sim 95 \%$ carbon dioxide).
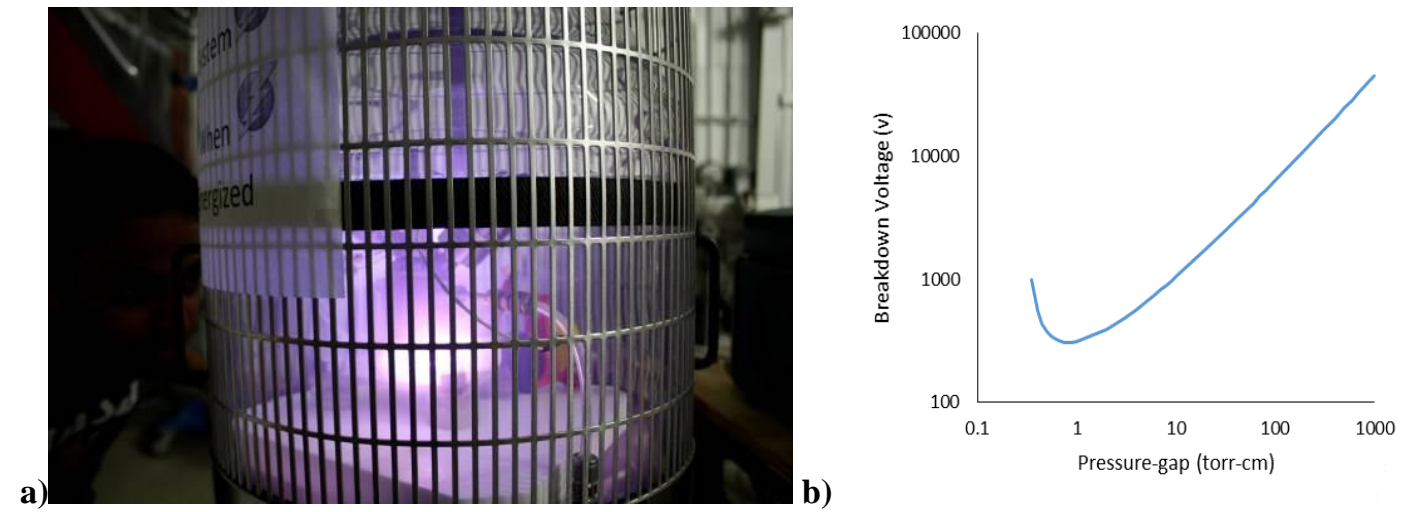

Figure 2. a) Corona discharge using a conventional automotive coil under vacuum conditions. b) Notional Paschen's curve for breakdown voltage in air.

Conventional spark plug systems typically use an induction coil to transform power supply voltage (e.g., 12 vdc or 24-32 vdc) into $>10^{3}$ volts to generate a spark. The sensitivity to corona discharge arises since the high-voltage cable, or "high tension lead," from the external coil to the spark plug itself carries voltage in excess of the minimum breakdown voltage, typically the $\sim 10^{2}-10^{3} \mathrm{~V}$ predicted in Paschen's curve. Electrical insulation surrounding the high voltage cable in many cases is insufficient to prevent corona discharge through the insulation and into the environment.

Previous space-qualified spark ignition systems used for upper-stage engines, e.g., J2 and RL10, included external exciter electronics, which were large in footprint and mass (some more than $5 \mathrm{lbm}$ ). These external boxes and their high voltage lead cables were typically hermetically sealed to reduce corona effects. However, loss of this purge could result in failure. Although this solution has proven reliable for main engine spaceflight applications, it would be excessively heavy for a spacecraft with a cryogenic reaction control system (RCS) that would require an exciter for each thruster (8-24 jets) on the vehicle. Other vehicle-integration-level considerations are the desire to move the igniter electronics away from the relatively cold environment and high shock levels at the RCS jets, typically on the extremities of the vehicle. By removing the igniter electronics from being co-located with the thrusters, the electronics may be housed with other avionics systems. Fig. 3 shows an example of how this architecture was implement on the ICPTA. Fig. 3a shows the original Project Morpheus vehicle diagram, which included individual exciters and high-voltage cables at each igniter. Fig. 3b shows the ICPTA implementation of coil-on-plug architecture with the igniter electronics co-located with the avionics and no high-voltage leads at the igniters. Note that the ICPTA used a $16 \mathrm{vdc}$ power system, but the coil-on-plug architecture also applies for spacecraft with 24-32 vdc power systems, which could generate higher spark energy or require lower current wires or smaller coils.

\section{B. NASA LOX/Methane Vacuum Spark Igniter Test Experience}

NASA previously tested spark-ignition systems for $\mathrm{LOX} / \mathrm{LCH}_{4}$ engines in simulated altitude conditions during the PCAD project in 2005-2010. During PCAD, some engines were tested in vacuum with external coils, with highvoltage leads that were either purged or pressurized. ${ }^{3}$ For example, during Aerojet 870 lbf LOX/LCH4 thruster simulated altitude testing at NASA White Sands Test Facility (WSTF), degraded spark output was observed if the exciter configurations were used without adequate vacuum protection on either the exciter or the high-voltage cable (e.g., loss of vacuum sealing or inadequate purge), thereby leading to no-light conditions. ${ }^{4}$ The Aerojet $100 \mathrm{lbf}$ LOX/LCH4 reaction control engine (RCE) was successfully tested at both WSTF and NASA Glenn Research Center (GRC) using a sealed external exciter. ${ }^{1,5}$ In addition to RCE testing, several LOX/LCH4 main engine test projects at WSTF during PCAD successfully demonstrated ignition in simulated altitude conditions using sealed external exciters. Main Engine test projects at WSTF included the Pratt and Whitney Rocketdyne RS-18, ${ }^{6}$ Armadillo Aerospace Main Engine, ${ }^{7}$ and Aerojet Ascent Main Engine ${ }^{1}$ (note that pyrotechnic ignition was also demonstrated on the Armadillo Main Engine). 


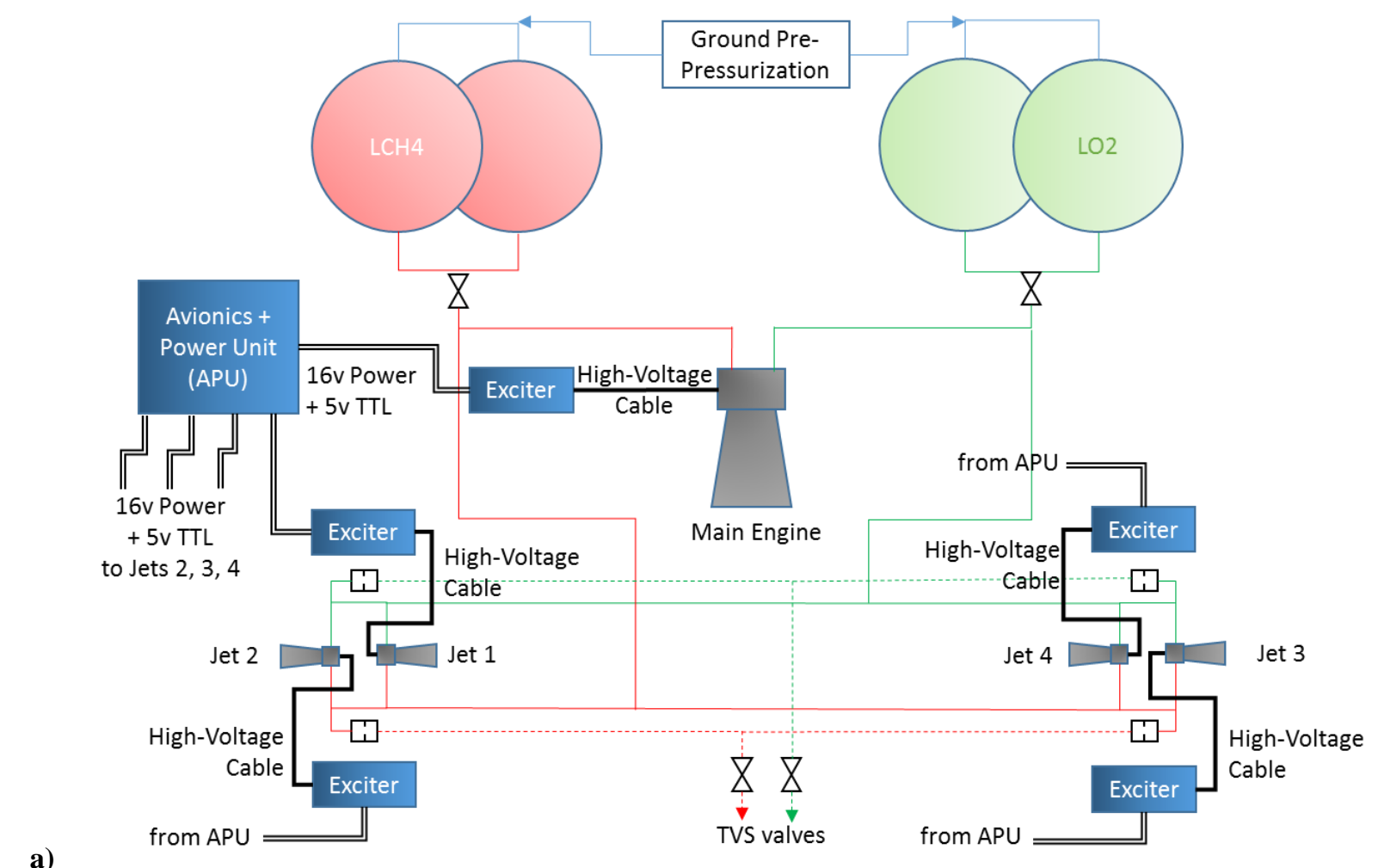

a)

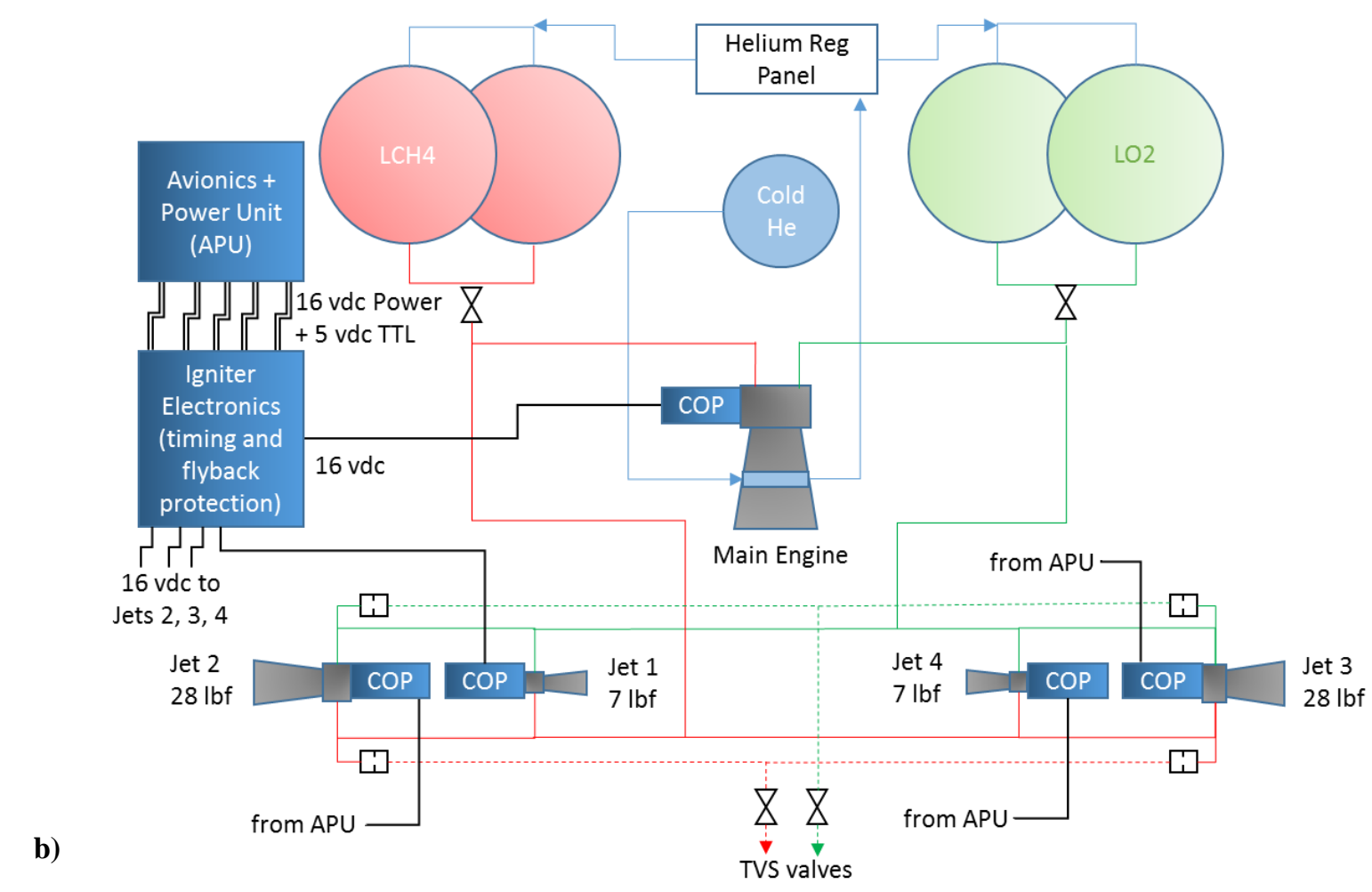

Figure 3. a) Project Morpheus ignition system (2011-2014), including distributed exciters and high-voltage leads at each igniter (note that Cold Helium Pressurization was added in 2015). b) Coil-on-plug ignition system implemented and tested on ICPTA (2016-2017) with igniter electronics co-located with avionics. 
NASA and its contractors successfully vacuum-tested "compact exciters," many of which were in "breadboard" or "proof of concept" development stage during PCAD. These tests proved that igniter devices can be successfully developed to eliminate the high-voltage lead and corona discharge effects. Under the PCAD project (Ref. 1), Unison developed a "compact exciter" that eliminated the high-voltage cables, and Small Business Innovative Research projects were completed with Alphaport. The Unison compact exciter was successfully demonstrated during simulated altitude testing on a $100 \mathrm{lbf} \mathrm{RCE}$ at NASA GRC at pressures ranging from 12 to 25 torr. ${ }^{8}$ For $\mathrm{LOX} / \mathrm{LCH}_{4}$ ignition testing, PCAD recommended that further investigation was still needed for igniters operating in cold thermal environments.

As part of ongoing LOX/LCH4 propulsion systems development since PCAD, NASA Marshall Space Flight Center (MSFC) has developed and tested an Augmented Spark Igniter system, which has also been tested at NASA GRC in altitude conditions. ${ }^{9}$ Testing successfully demonstrated two different commercial compact systems: one compact exciter without a high-voltage lead, and one conventional exciter with an improved high-voltage cable. Both exciter configurations successfully demonstrated ignitions at altitude conditions down to $\sim 25$ torr.

In 2016-2017, hot-fire testing was conducted on the NASA JSC ICPTA at NASA GRC Plum Brook Station. This test project was completed as part of Plum Brook Test Cell B-2 facility characterization project, and provided an opportunity to test integrated $\mathrm{LOX} / \mathrm{LCH}_{4}$ propulsion technologies using the ICPTA at simulated altitude conditions and thermal cold-wall conditions. More information regarding the test project can be found in Ref. 10. The ICPTA uses an integrated, pressure-fed, cryogenic LOX/LCH4 propulsion system including an RCS with two $28 \mathrm{lbf}-\mathrm{vac}$ and, two $7 \mathrm{lbf}$-vac engines, and one 2,800 lbf-vac main engine (RCS shown in Fig. 4). Details of the ICPTA RCS can be found in Ref. 11. Previous sea-level testing of the ICPTA during Project Morpheus used conventional automotive spark plugs with external coils connected by high-voltage cables (Fig. 5a). The ICPTA spark plug + coil devices were replaced with coil-on-plug (COP) spark ignition devices (Fig. 5b) for the simulated altitude testing, which eliminated the high-voltage cable and risk of corona discharge energy losses.

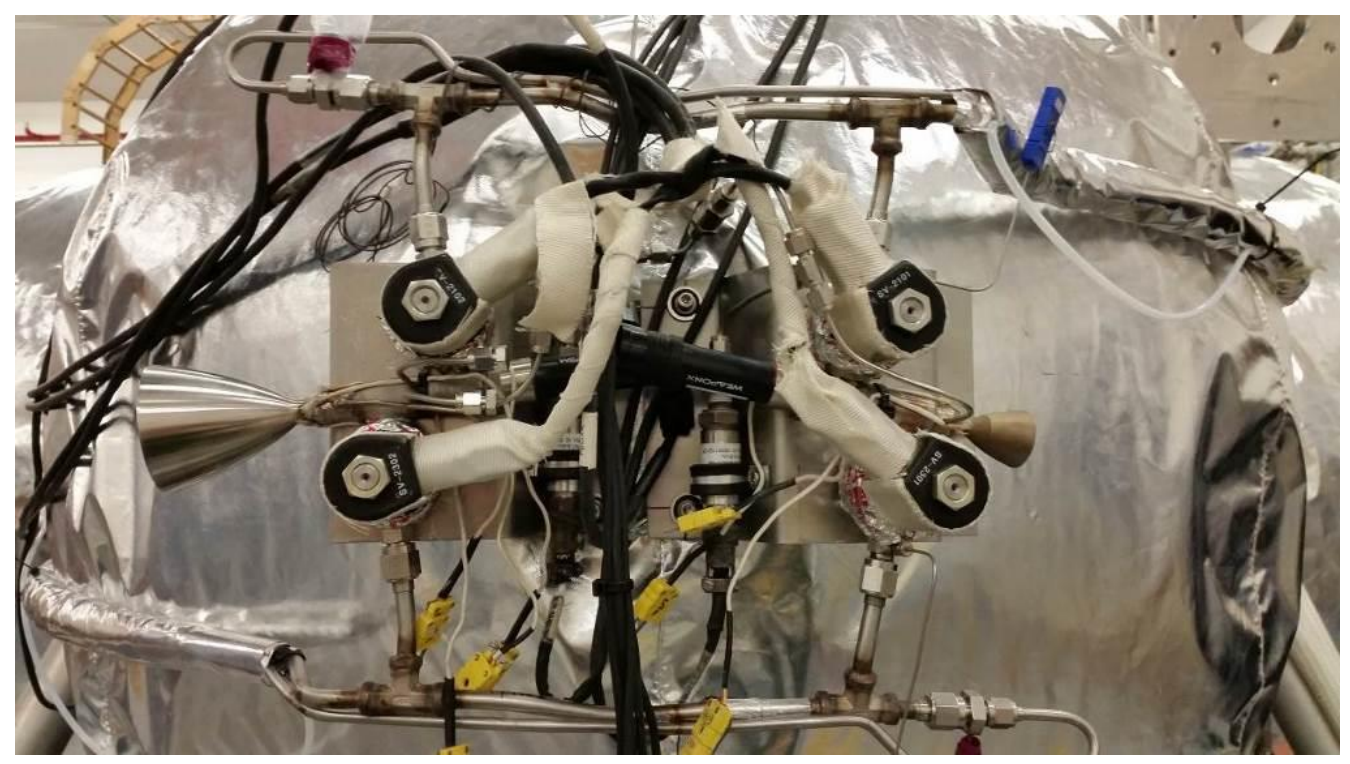

Figure 4. ICPTA RCS pod with one $28 \mathrm{lbf}$-vac engine (left) and one $7 \mathrm{lbf}$-vac engine (right) installed with coil-on-plug (COP) spark igniters (note, main engine not shown). 

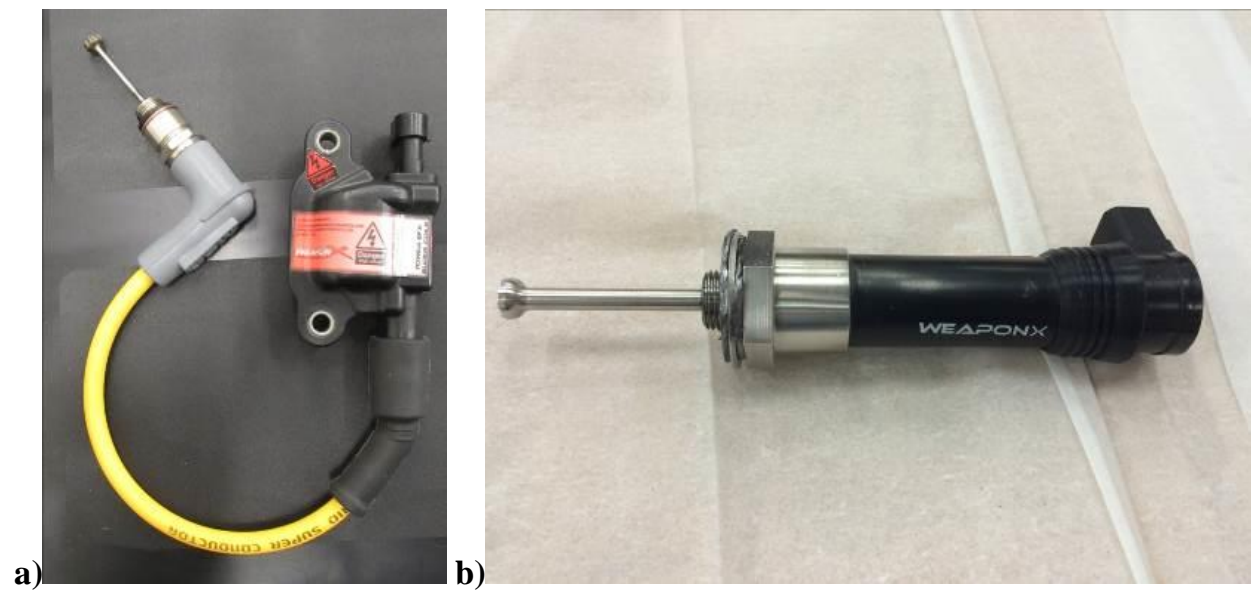

Figure 5. a) Conventional spark plug with external coil and high-voltage cable used during sea-level testing. b) COP plug system used for simulated altitude testing.

\section{Test Article Description}

For simulated-altitude ICPTA testing, NASA worked with commercial vendors to modify off-the-shelf racing automotive heritage coil-on-plug spark plug systems for use with LOX/LCH4 igniters (Fig. 5b). WeaponX Performance Products, LTD fabricated the coil, and the vendor custom-modified the coil to be vacuum-potted into a threaded interface nut to mount into the existing spark plug ports on the ICPTA RCE and main engine igniters (Fig. 6). NASA separately fabricated electrode tips, which were then thread-mounted into the potted coil body. The vacuum potting prevented pressure/vacuum leakage into the coil body and maintained the spark location at the electrode tip. The electrodes were custom-built separately, so that the coils or electrodes could be line-replaceable within each RCE or main engine igniter, which had different electrode geometries. The vendor-supplied coils operate by inductive discharge, which allows for much longer spark times compared to capacitive discharge systems.

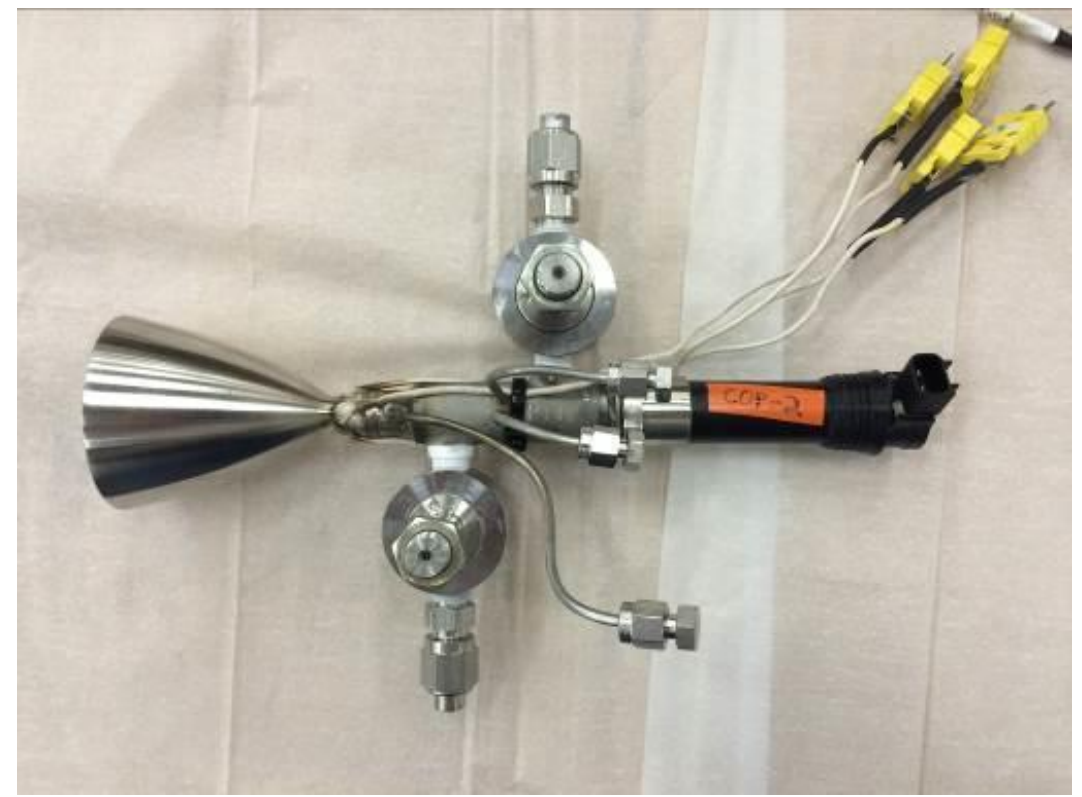

Figure 6. 28 lbf-vac RCE with COP igniter installed. 
The epoxy insulation selection was initially completed by the vendor and required a high dielectric strength to maintain insulation between the electrode at $\sim 10^{3}-10^{4} \mathrm{vdc}$ and the thread adapter, which is grounded into the body of the igniter. Furthermore, the potting must be able to survive both cold and hot thermal conditions. For example, the RCE electrode tip can experience liquid oxygen temperatures down to $-290^{\circ} \mathrm{F}$ or less, whereas the main engine igniter electrode tip can experience combustion temperatures greater than $1000^{\circ} \mathrm{F}$. The potting was installed in the coil body under vacuum conditions to prevent voids.

Subsequent testing at NASA showed that additional modifications for the potting and electrode thermal and electrical insulation were needed to increase COP life in the hot-gas main engine igniter environment. For example, the hot-gas environment inside the igniter could lead to epoxy erosion and arc-tracking along the exposed epoxy surface, which resulted in the loss of spark at the electrode tip. A combination of ceramic insulators, hightemperature potting, and the elimination of Kapton tape was required to produce a long-life COP. Although test results demonstrate that the devices provide adequate spark energy for ignition, further development is needed in ceramic and high-temperature epoxies for the igniter application.

The coils integrated into the ICPTA were originally designed for $12 \mathrm{vdc}$ automotive systems, but were operated at $16 \mathrm{vdc}$ using facility power supplies. This configuration was initially tested stand-alone in a vacuum bell jar and was later adopted as the ICPTA baseline. A single $24 \mathrm{vdc}$ coil was also tested, stand-alone, in the vacuum bell jar at $28 \mathrm{vdc}$ to better represent a flight-like power system (e.g., 28-32 vdc). No new issues were uncovered in the $28 \mathrm{vdc}$ vacuum bell jar testing, and neither the $12 \mathrm{vdc}$ nor $24 \mathrm{vdc}$ coils demonstrated any corona discharge.

The ICPTA trigger command for all the igniters is 100 sparks per second at $50 \%$ duty cycle, which was the heritage command output of the ICPTA controller from Project Morpheus. The coil vendor recommended maintaining the duty cycles at $12 \%$ to $15 \%$ to increase life and avoid overheating the coils. Vacuum bell-jar performance testing revealed that adequate thermal margin was maintained when operating at the high $50 \%$ duty cycle, even after several minutes of continuous operation (albeit with temperatures continuously rising). Cumulative operation time over the complete test campaign was expected to be less than 5 minutes per coil, hence electronics life beyond the test campaign was not a concern.

The target spark energy requirement for the ICPTA was $35 \mathrm{~mJ}$ based on successful ignition reliability during Project Morpheus. Testing on the $12 \mathrm{vdc}$ coil with $16 \mathrm{vdc}$ power supply demonstrated only $22-24 \mathrm{~mJ}$ spark energy at 50\% duty cycle (described below). Vendor testing proved that the $24 \mathrm{vdc}$ coil met the $35 \mathrm{~mJ}$ requirement with duty cycles as low as $13 \%$.

In the configuration that was tested in 2016-2017, the coil body did not include the electronics (e.g., transistors) to produce a high frequency spark using the $16 \mathrm{vdc}$ power and the $5 \mathrm{vdc}$ Transistor-Transistor Logic (TTL) trigger. Instead, the ICPTA testing included a vendor-supplied ignition electronics device to perform the switching, accepting a continuous $16 \mathrm{vdc}$ input and then sending a $16 \mathrm{vdc}$ pulse to the COP transformer for each $5 \mathrm{vdc}$ trigger signal at $100 \mathrm{~Hz}$. This device was not vacuum-rated prior to testing, however, requiring the igniter electronics module to be installed outside of the vacuum test cell during ICPTA testing. In addition to the switching electronics, a vendor-supplied "condenser" was included to help reduce voltage flyback from the igniter to the APU controller. Subsequent development work by the vendor may provide a switching device capable of being integrated onto the igniter body.

The igniter electronics were co-located with the ICPTA avionics and power unit (APU) controller outside of the vacuum test cell in a purged enclosure (Fig. 7). This configuration included a $\sim 50 \mathrm{ft}$ wiring harness from the electronics to the test article, which not only included the igniter power circuits (now at high amperage, 7-9 amps at $100 \mathrm{~Hz}$ ), but also more than 120 other APU command and data channels fed through a common bundle and test cell vacuum feedthrough connector (note that ICPTA had more than 350 command/data channels total, including those recorded by facility data systems). Stand-alone Electro-Magnetic Interference (EMI) testing was not conducted on the wiring harness; however, multiple functional checkouts of the system operation and data integrity were conducted during build-up and sea-level testing prior to the Plum Brook testing. All of the command and data wiring in the harness used shielded, twisted pair wiring, with the exception of the thermocouple wires. Data analysis conducted to date has not yet revealed a significant EMI effect during COP firing on the APU data channels recorded at $100 \mathrm{~Hz}$, but further data analysis is in work. 

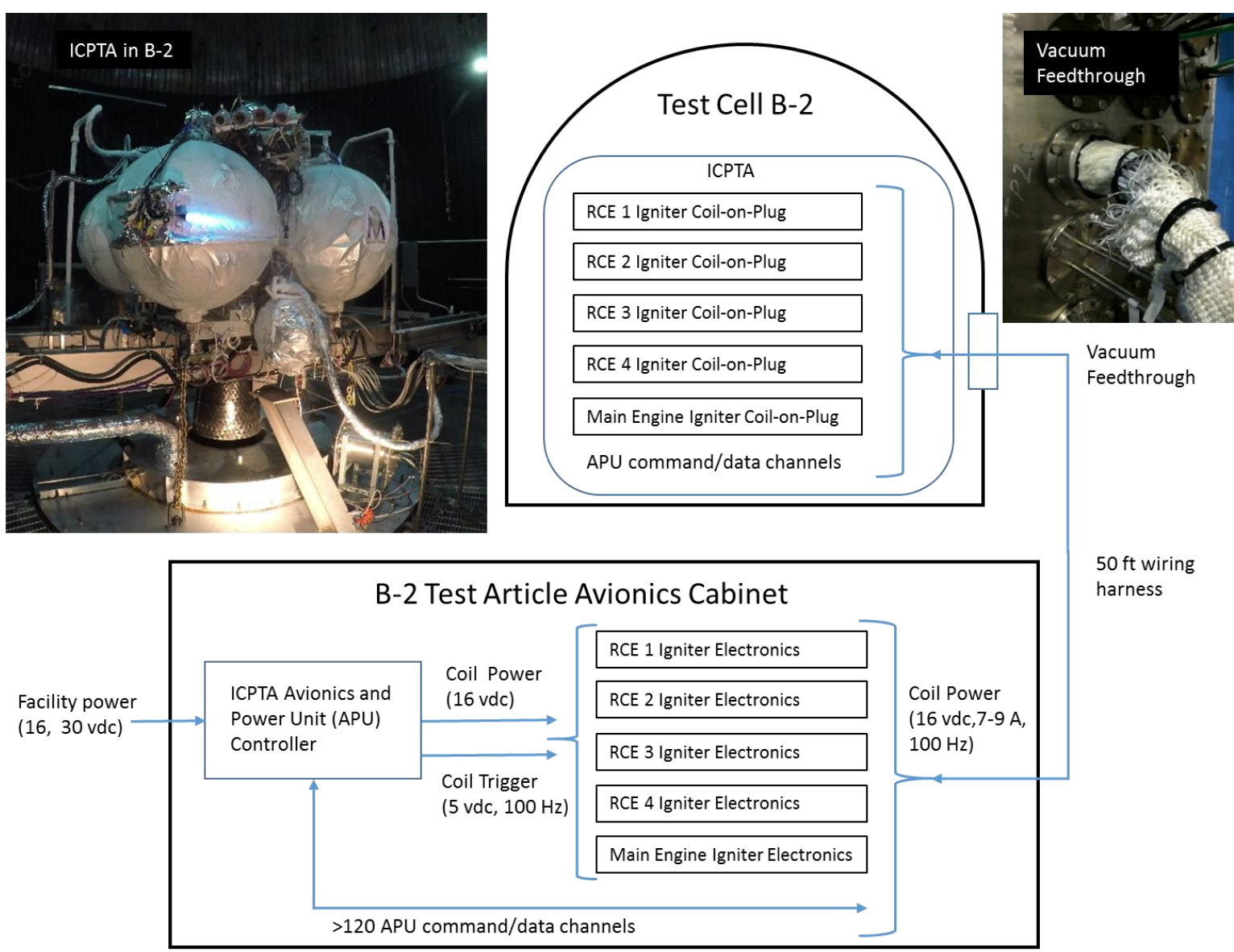

$50 \mathrm{ft}$ wiring

harness
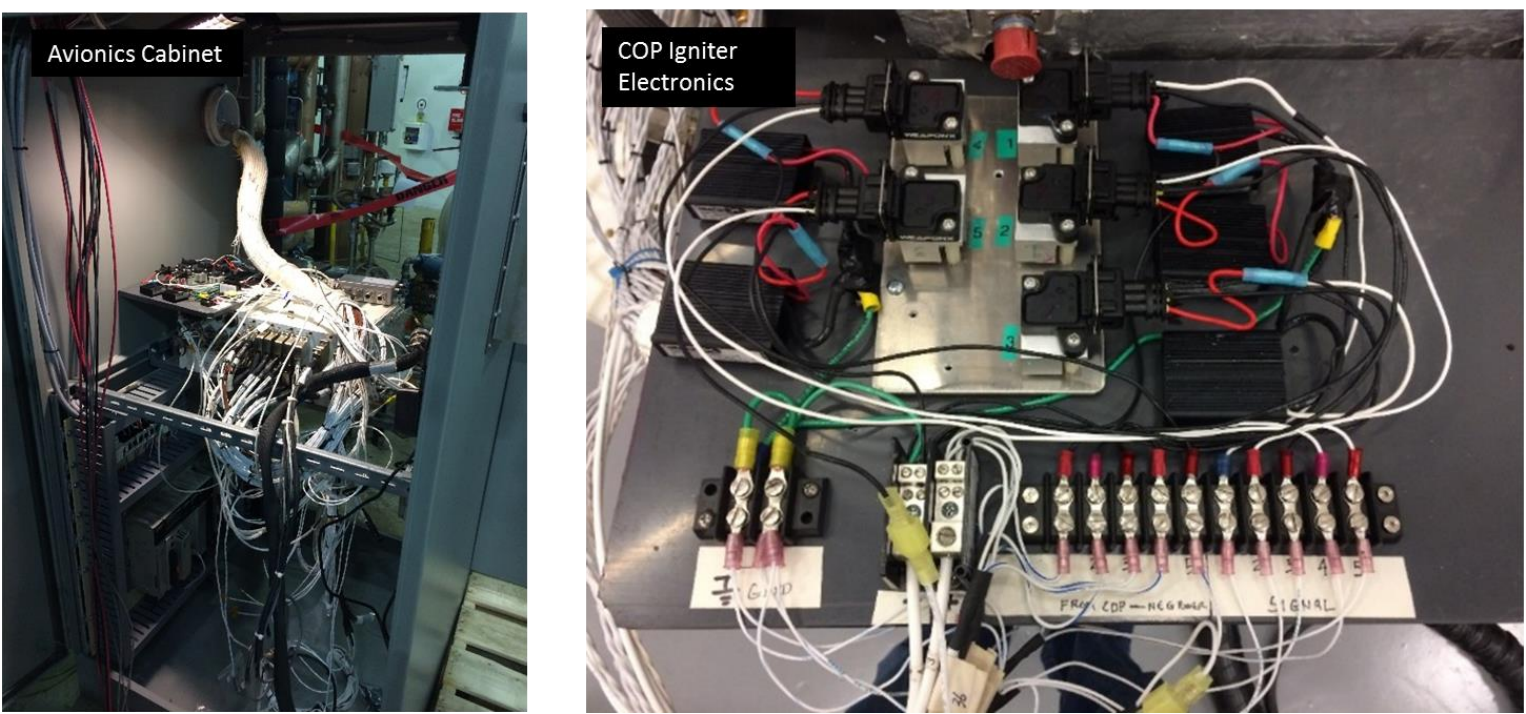

Figure 7. Electrical layout of ICPTA coil-on-plug ignition system used at Plum Brook B-2 for ICPTA hot-fire testing.

8

American Institute of Aeronautics and Astronautics 


\section{Test Results}

\section{A. Vacuum Bell Jar and Bench Top Electrical Testing}

Prior to ICPTA testing at Plum Brook, tests at NASA Johnson Space Center (JSC) demonstrated the performance of the coil-on-plug igniters at a component level. First, electrical tests were conducted in a vacuum bell jar to prove no corona discharge would be observed external to the coil during electrical operation from 50 to $10^{-4}$ torr (Fig. 8). In this test configuration, the COP and electronics were exposed to a vacuum environment whereas the spark plug tip was exposed to ambient 14.7 psia conditions. Both the ICPTA 12 vdc coils and the pathfinder $24 \mathrm{vdc}$ coils were tested. The electrical tests both in ambient bench-top and vacuum bell jar configurations were conducted without the ICTPA controller (APU). Tests were completed using 12 vdc benchtop power supplies and breadboard circuits for the $5 \mathrm{vdc}$ trigger signal. During these tests, troubleshooting was completed on several issues that occurred with the firing circuit being related to the use of function generators and high-voltage probes that were not part of the ICPTA configuration.

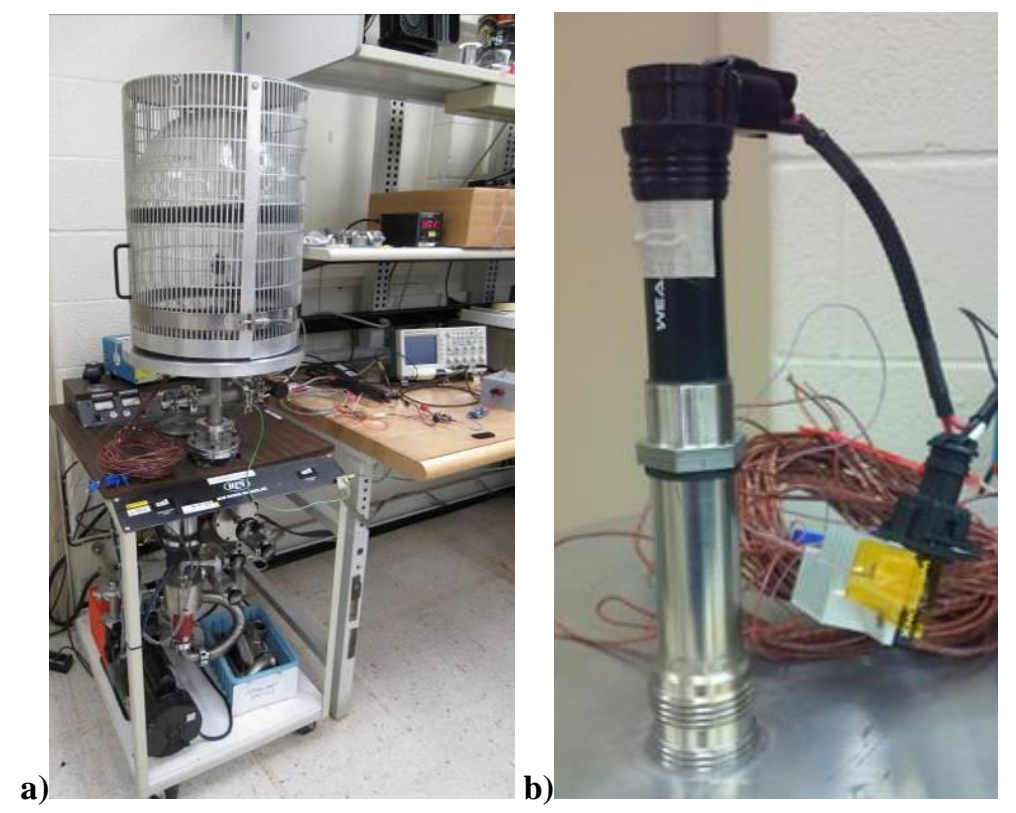

Figure 8. a) Vacuum bell jar electrical test configuration for the coil-on-plug igniter. b) Close-up of the coil mounted to the bell-jar feedthrough.

Corona discharge was not observed on the $12 \mathrm{vdc}$ coils at pressures ranging from 50 to $10^{-4}$ torr nor on the $24 \mathrm{vdc}$ coils at pressures from 50 to $10^{-2}$ torr during this testing. Tests were conducted on the $12 \mathrm{vdc}$ coil up to $\sim 115 \mathrm{sec}$ in duration, and the $24 \mathrm{vdc}$ coil was tested up to $\sim 15 \mathrm{sec}$. All testing was performed at $50 \%$ duty cycle.

Benchtop testing was conducted to measure spark energy for the $12 \mathrm{vdc}$ coil. This testing was conducted at ambient conditions instead of the vacuum bell jar because the bell jar configuration did not permit a direct electrode current discharge measurement. The high-voltage measurement was made at the electrode, and current was measured through the grounding path discharge wire (Fig. 9). The $12 \mathrm{vdc}$ coil measurements showed a spark energy of $\sim 22-24 \mathrm{~mJ}$ when powered by $16 \mathrm{vdc}$ input. The previous conventional $12 \mathrm{vdc}$ coil used on the ICPTA during Project Morpheus was re-tested at $16 \mathrm{vdc}$ input and demonstrated $\sim 37 \mathrm{~mJ}$ spark energy. The measured spark energy was acceptable to begin hot-fire testing checkouts based on previous test history during PCAD that demonstrated successful ignition at even lower spark energy levels during some projects. Note that spark energy was never measured in the exact configuration of the integrated ICPTA vehicle testing using the vehicle 16 vdc power supply or controller. 


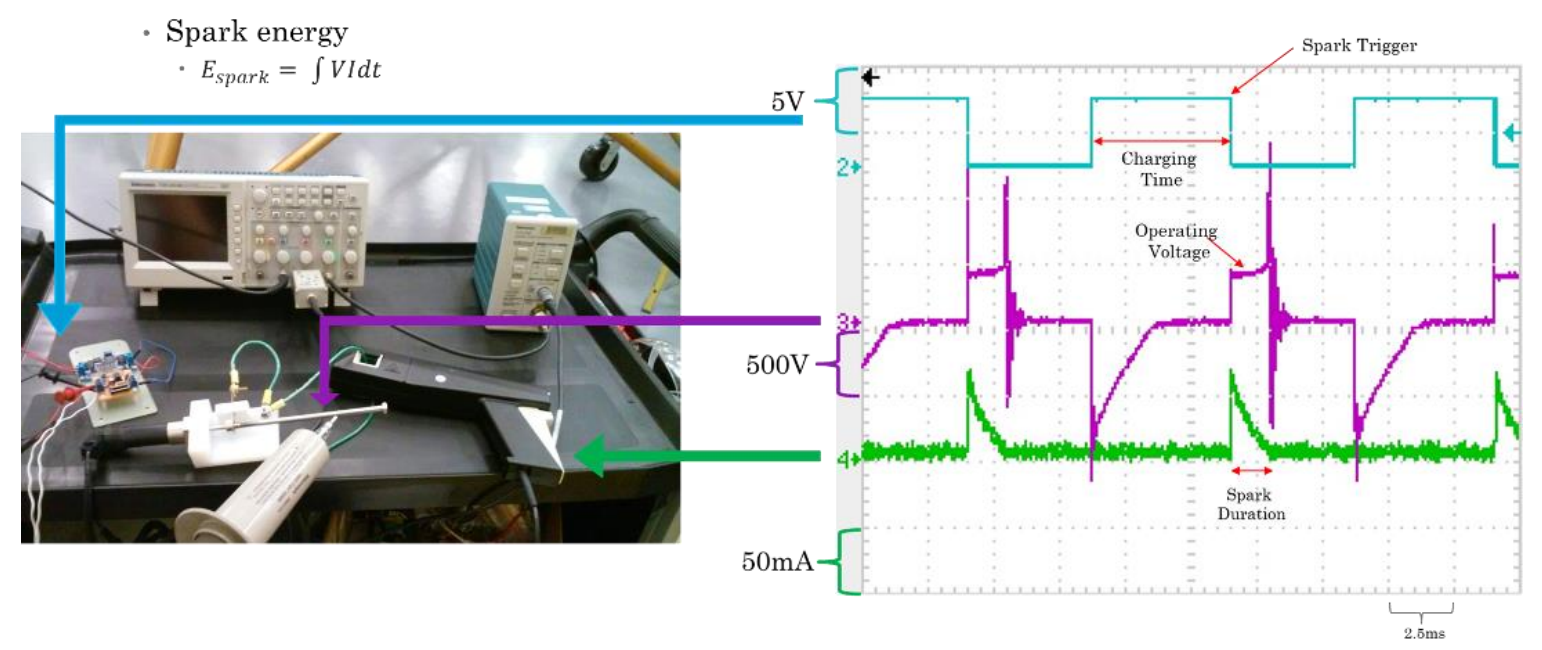

Figure 9. Bench-top setup to test coil spark energy.

The electrical firing circuit was also improved to prevent high-voltage flyback into the electronics and improve grounding. Flyback was measured as high as $75 \mathrm{vdc}$ in some instances. A vendor-supplied condenser was added to the circuit to reduce the voltage flyback magnitude. Additionally, test results were improved when the grounding path was shortened and made more robust. Flyback voltage was reduced down to $<20$ vdc by using the ICPTA Plum Brook configuration of $\sim 50 \mathrm{ft}$ wiring length and the vendor-supplied condenser. The ICPTA test team accepted this magnitude of voltage flyback after the sea-level conventional coil used during Project Morpheus was similarly measured to generate flyback voltages up to $30 \mathrm{vdc}$. Thousands of ignitions using this style of coil without incident during Project Morpheus demonstrate the ICPTA controller's tolerance of this voltage flyback magnitude.

A thermocouple was added to the coil body during these vacuum bell jar tests to measure the temperature of the coil during extended run times. The max temperature recorded was $130^{\circ} \mathrm{F}$, which fell within the manufacturer recommended maximum allowable temperature of $200^{\circ} \mathrm{F}$.

\section{B. Vacuum Component-Level Hot-Fire Testing}

Component-level hot-fire testing was performed on the ICPTA 28 lbf-vac RCE, $7 \mathrm{lbf}$-vac RCE, and the main engine igniter. The test series was conducted on the NASA JSC CryoCart test bed (Fig. 10a), both at ambient and vacuum conditions. The CryoCart test bed is a mobile LOX/LCH4 propulsion test article capable of testing RCE in the $100 \mathrm{lbf}$ (or smaller) thrust range. A new "vacuum pipe" test fixture was designed and fabricated to facilitate ignition testing at vacuum conditions (Fig. 10a and 10b). The vacuum pipe included an intrinsically safe flapper door designed to open when the pipe pressure rose to ambient pressure, but would allow for short-duration ignition demonstrations of the RCE and main engine igniter. Test durations in the vacuum pipe were limited based on a hazard analysis that conservatively bounded the potential combustible environments that would be generated during a potential RCE no-light condition. The $28 \mathrm{lbf}-\mathrm{vac} \mathrm{RCE}$ testing was limited to $200 \mathrm{msec}$ maximum run time, the 7 lbf-vac RCE testing was limited to $700 \mathrm{msec}$, and the main engine igniter testing was limited to $500 \mathrm{msec}$. A highflow gaseous nitrogen purge was activated in the vacuum pipe at the end of each individual thruster test sequence to purge any burned or unburned gases from the pipe.

The ICPTA controller was not used for the vacuum pipe testing, nor was the Plum Brook configuration $\sim 50 \mathrm{ft}$ harness. Instead, the CryoCart onboard National Instruments CompactRIO control and data acquisition system was used. Spark coil power and triggering was controlled from the CryoCart CompactRIO through solid-state relays commanding a stand-alone power supply and the same spark trigger breadboard circuit that had been used during benchtop electrical testing. The power supply was an Extech Model 38225 1-30 vdc. 1-20 Amp variable power supply set to $16 \mathrm{vdc}$ and high-allowable current limiting (e.g., 10-12 Amp). The igniter electronics were installed outside of the vacuum pipe environment, similar to the Plum Brook test configuration. 

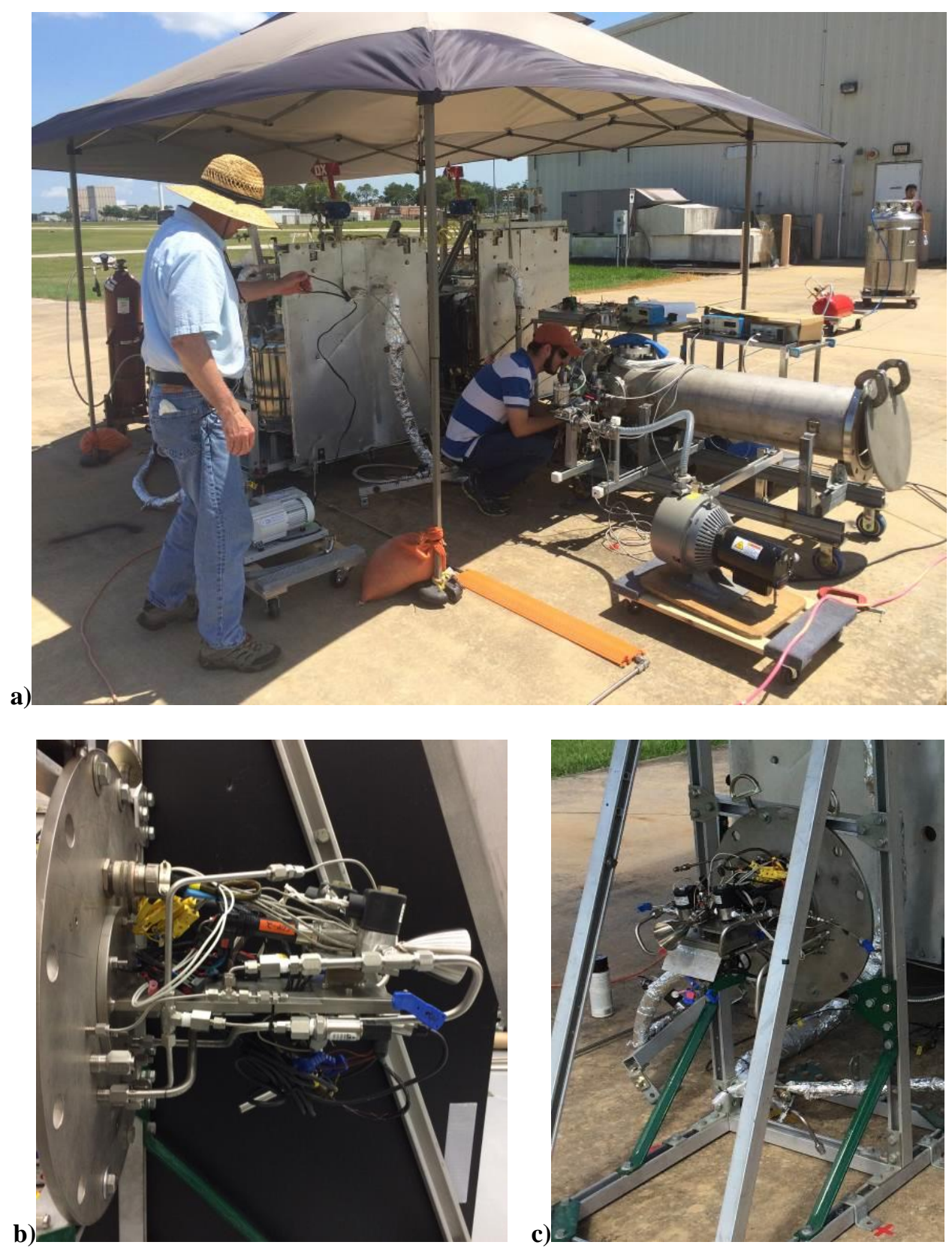

Figure 10. a) CryoCart test article with vacuum pipe apparatus for hot-fire testing. b) 28 lbf-vac RCE with coil-on-plug igniter mounted on vacuum pipe interface plate. c) 28 lbf-vac thruster mounted on ambient checkout test stand.

Prior to the start of vacuum-pipe hotfire testing, checkout hotfire testing at ambient pressure showed that modifications to the spark electrode insulation were required to prevent epoxy erosion in the hot-gas environments of the igniters. Fig. 10c shows the RCE stand in the ambient-test configuration. The RCE tests demonstrated 163 lights with one no-light attributed to a coil failure. The main engine igniter demonstrated 10 successful tests at ambient conditions with no coil failures. Additional no-lights were observed due to test configuration errors (e.g., incorrect/intermittent wiring or incorrect/insufficient orificing) or propellant conditioning (e.g., methane inlet conditions being too cold), and are described in more detail in Ref. 11.

Tests of the $28 \mathrm{lbf}$-vac RCE demonstrated vacuum ignition at 50 to 0.03 torr (Fig. 11a). The first vacuum test conducted demonstrated a no-light due to propellant conditioning; however, the remaining nine tests on the 28 lbf-vac RCE were successful. Next, nine vacuum tests were conducted on the main engine igniter with zero "no 
lights" in vacuum conditions (Fig. 11b). Tests of the $7 \mathrm{lbf}$-vac RCE were the last tests performed in the test campaign, and they demonstrated vacuum ignition at $\sim 3-4$ torr. A summary of the CryoCart Vacuum Pipe component-level test conditions is shown in Table 1.
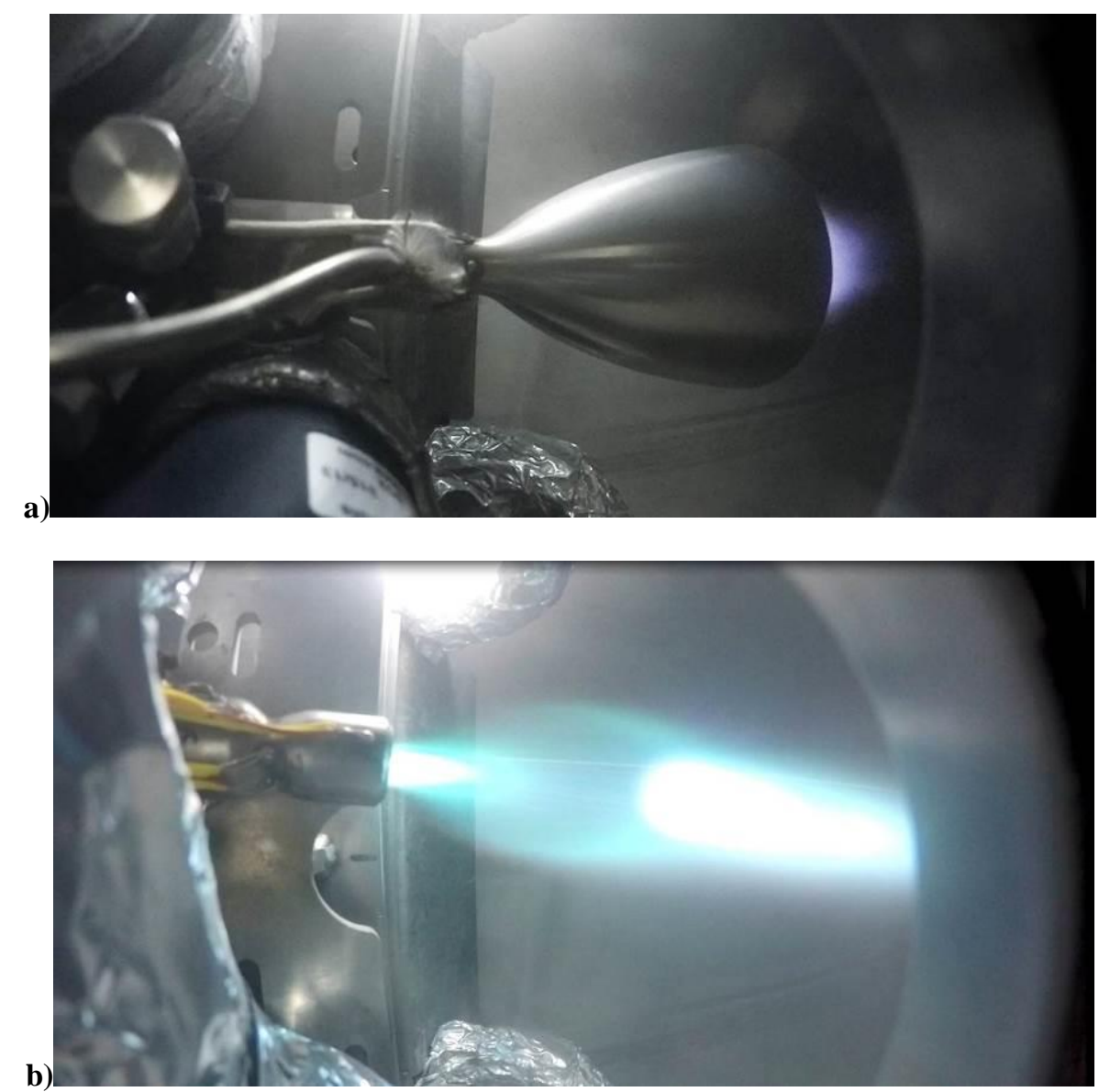

Figure 11. Hotfire testing at vacuum conditions in the CryoCart Vacuum Pipe using coil-on-plug igniters: a) 28 lbf-vac RCE. b) Main engine igniter.

Table 1. Summary of Vacuum Test Conditions for Component-level Hot-Fire Testing on the CryoCart Vacuum Pipe Test Apparatus at JSC

\begin{tabular}{|l|l|l|l|}
\hline Test Conditions & $\begin{array}{l}\text { 28 lbf-vac RCE } \\
\text { tests (torr) }\end{array}$ & $\begin{array}{l}\text { ME Igniter tests } \\
\text { (torr) }\end{array}$ & $\begin{array}{l}\text { 7 lbf-vac RCE } \\
\text { tests (torr) }\end{array}$ \\
\hline $\mathbf{1 0}$ to $\mathbf{5 0}$ torr & $50,20,10$ & $10,20,50$ & \\
\hline $\mathbf{1}$ to $\mathbf{1 0}$ torr & $1.5^{*}, 2.3,2.9,1.2$ & 1.4 & $2.6,4,4$ \\
\hline $\mathbf{0 . 1}$ to $\mathbf{1}$ torr & 0.35 & $0.67,0.97,0.15,0.1$ & \\
\hline $\mathbf{0 . 0 1}$ to $\mathbf{0 . 1}$ torr & $0.03,0.065$ & 0.025 & \\
\hline
\end{tabular}

Note: * no-light due to propellant conditioning

The test effort on the $7 \mathrm{lbf}$-vac thruster was reduced to only three tests following the successful testing of the $28 \mathrm{lbf}$-vac and the main engine igniter. Tests conducted at $\sim 1$ torr or higher were completed using a scroll pump; tests less than $\sim 1$ torr required a turbo-molecular vacuum pump and complex test operations to reduce vacuum leakage. Further risk-reduction testing for the $7 \mathrm{lbf}$ was not conducted because of the increased test costs and time for the $<1$ torr testing. The technical risk was considered acceptable based on the $28 \mathrm{lbf}$-vac and main engine igniter test successes. 


\section{Sea-Level Integrated Hot-Fire Testing}

The final test series at NASA JSC for the coil-on-plug included fully integrated hot-fire testing of the ICPTA, with tests demonstrating simultaneous main engine and RCS operation at sea-level conditions (Fig. 12). The tests were conducted as part of vehicle risk reduction prior to delivery to Plum Brook due to configuration changes on the vehicle, including the use of a newly fabricated main engine injector and a complete disassembly and reassembly of the propulsion system for insulation and vacuum-rated actuators. These tests were conducted on the JSC on-site antenna test range where previous Project Morpheus and Cold Helium ICPTA testing was conducted from 20122015. The vehicle was suspended from a crane in a static position over a main engine hot-fire flame trench. The vehicle-level tests included the Plum Brook configuration avionics using the ICPTA controller (APU) and the $\sim 50 \mathrm{ft}$ vacuum feedthrough connector (Fig. 12a).
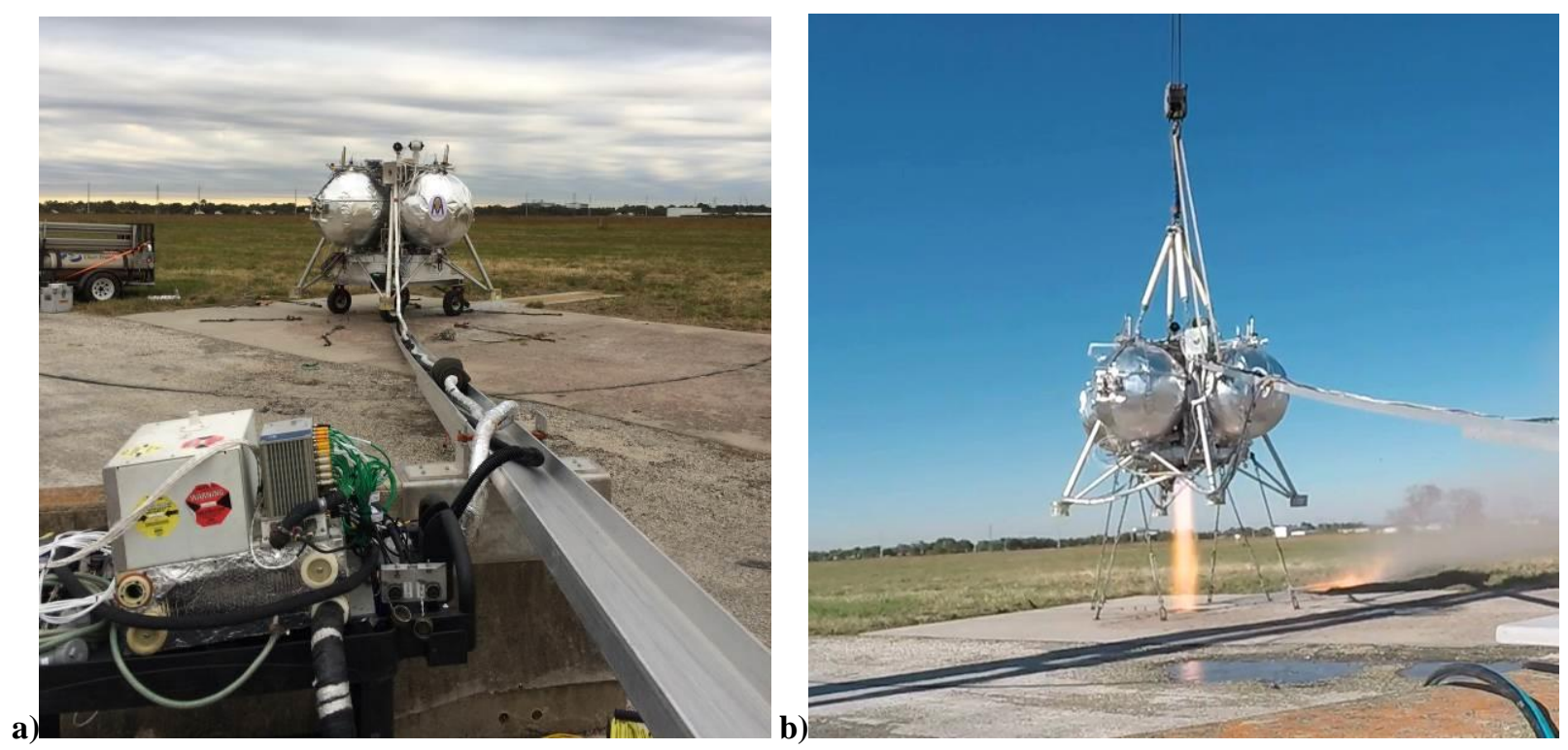

Figure 12. a) ICPTA sea-level hot-fire configuration with Plum Brook $50 \mathrm{ft}$ avionics harness. b) Hot-fire demonstration with main engine and RCS simultaneous operation with coil-on-plug igniters.

The integrated vehicle hot-fire tests successfully proved that the integrated electronics could operate all five of the coil-on-plug igniters simultaneously and in test sequence (e.g., main engine with RCS pulsing) without significant EMI problems or voltage flyback problems into the ICPTA avionics and power controller. The only remaining configuration not tested during the JSC ICPTA sea-level tests was the Plum Brook facility power supply to the ICPTA controller (APU). For the JSC testing, the APU was powered by JSC-provided 16 and 32 vdc power supplies powered by a gasoline generator.

During the sea-level integrated testing, failures of the COP around the spark tip revealed that additional electrode epoxy and ceramic insulation improvements were required, specifically on the main engine igniter. Following an initially successful main engine igniter-only demonstration test, the main igniter COP failed to reliably provide spark energy at the electrode due to the epoxy/ceramic installation. Arc tracking along a Kapton tape boundary and internal air gaps between the epoxy and ceramic insulators were suspect failure modes. Two different tests on the main engine were unsuccessful and required main engine igniter COP repair and replacement with an improved ceramic installation process and screening. The modified COP were then rescreened, and subsequent vehicle-level testing was successful.

The RCE COP igniters successfully demonstrated hot-fire testing without any COP failures in 88 tests. The main engine igniter successfully demonstrated hot-fire testing in nine tests following the repair work, including simultaneous main engine and RCE sequences (Fig. 12b).

\section{Simulated Altitude Integrated Hot-Fire Testing}

ICPTA testing in the Plum Brook B-2 facility was conducted at simulated altitude conditions and in both ambient-temperature and cold thermal conditions (Fig. 13a). The first set of tests was performed under ambient temperature and simulated altitude pressure conditions of $\sim 30$ torr. These tests consisted of a range of minimum 
impulse bit (MIB) pulsing sequences with low duty cycle, analogous to a coast phase in which the RCS is primarily used for station keeping. Higher duty cycle pulsing tests were also performed, analogous to an ascent or landing mission phase. Lastly, tests with longer pulses and multiple engines firing either in sequence or simultaneously were run to gather transient system response data. Integrated tests were also performed to demonstrate simultaneous main engine and RCS operation (Fig. 13b). Details of the test campaign can be found in Ref. 10, and a detailed description of the RCS test results are described in Ref. 11. The baseline test plan included testing at much lower pressures; however, those test conditions were not achieved due to vehicle system leakage and facility vacuum leakage.

a)
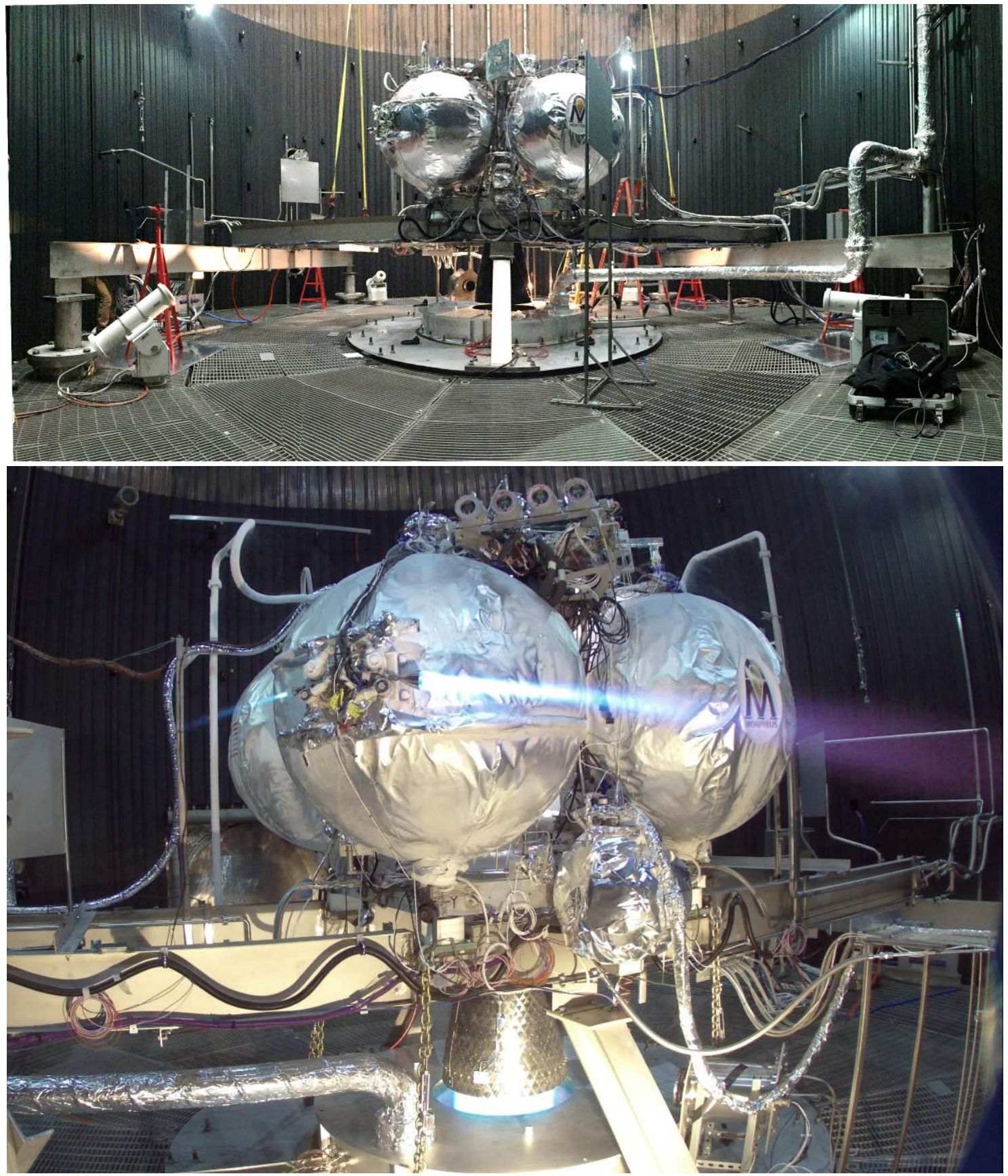

Figure 13. a) ICPTA installation in Plum Brook B-2 test cell. b) Integrated hot-fire demonstration with 7 lbf-vac RCE, 28 lbf-vac RCE, and main engine simultaneous operation. 
During the ambient temperature vacuum testing, 959 successful RCE hot-fire tests were completed without any COP failures during hot-fire test. No vacuum corona discharge was observed in any of the test conditions external to the coil bodies. Some no-lights on the RCS were observed; however, these were attributed to propellant conditioning, as was observed during sea-level component-level testing. One RCE COP failure was identified during electrical/command functional checkouts (i.e., not during hot-fire) that was attributed to arc-tracking epoxy issues. This was discovered between hot-fire tests, and the COP was successfully repaired and re-installed with no further issues.

Similar to sea-level integrated testing, the main engine igniter COP demonstrated one failure to provide spark energy at the electrode during the ambient-temperature altitude testing due to high-temperature erosion at the spark tip in the main engine igniter, possibly due to arc tracking. Subsequent replacement of the electrode ceramic insulation was required. During the test campaign, 19 successful main engine igniter lights were demonstrated in igniter-only testing, main engine testing, and integrated testing.

The electrical system performed as expected following the sea-level integrated tests. No new issues were uncovered while operating the spark coils in the Plum Brook installation using the facility power supply. No new EMI issues were uncovered in the ICPTA controller (APU) data. Some Plum Brook high-speed data channels (that were not included in the sea-level testing at JSC) did include some $120 \mathrm{~Hz}$ electrical noise during coil firings, but the amount of noise was acceptable within signal-to-noise tolerances for the high-speed data analysis. Note that these channels were not co-bundled with the low-speed APU data harness that included the COP high-current wiring.

\section{E. Thermal-Vacuum Integrated Hot-Fire Testing}

The last set of tests were performed with the B-2 cold wall active, flooded with liquid nitrogen, and the vehicle was under cold soak for more than $\sim 40$ hours. The average test cell temperature was $\sim-305^{\circ} \mathrm{F}$ during this cold soak, and pressures began at around 0.02 torr. By the time RCS testing began, the test cell pressure had increased to $\sim 6$ torr due to vehicle and test cell vacuum leakage. RCE jet body temperatures, including the COP, reached $\sim-200^{\circ} \mathrm{F}$ to $-225^{\circ} \mathrm{F}$. The RCE jet body temperatures dropped to $<-300^{\circ} \mathrm{F}$ in some cases as the RCS was conditioned for hot-fire.

Several no-lights (or quenched lights) were observed on the RCE under the cold thermal conditions that were successful at ambient temperature environment under similar propellant inlet conditions (Fig. 14a). Two successful RCE pulses were demonstrated on the RCE after warm gaseous nitrogen purge flow was introduced to warm the jet bodies to $\sim-150^{\circ} \mathrm{F}$ before light (Fig. 14b). One RCE coil mechanically failed during these cold thermal conditions due to inadequate plastic-to-metal bonding of the coil body housing. Further RCS hot-fire testing was not attempted within the test campaign time remaining. The main engine igniter was not tested under the cold thermal conditions due to other system leakage on the ICPTA.

a)
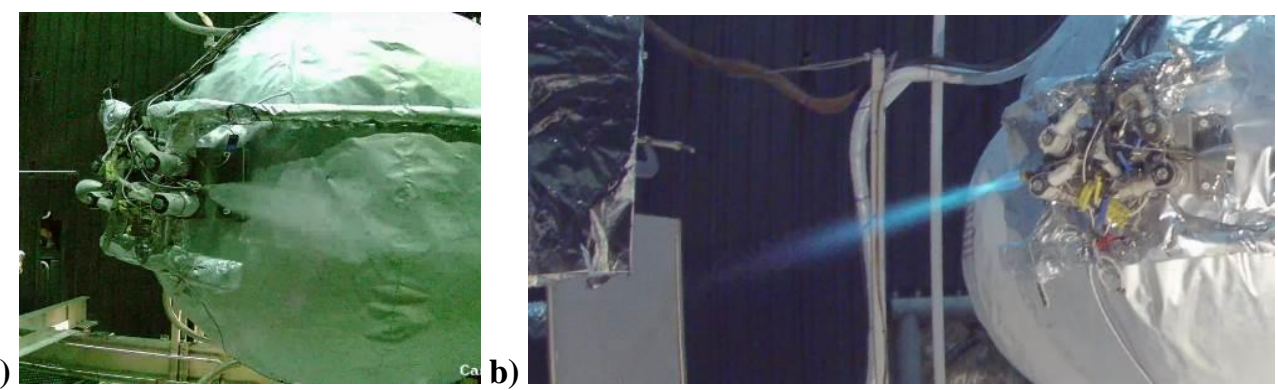

Figure 14. Cold Thermal Wall Test Imagery of ICPTA RCS testing. a) No-light coldflow (quenched flow). b) Successful jet hot-fire after warm gaseous nitrogen purge flow.

The root cause of the no-lights/quenched-lights in the cold thermal conditions is still under review; more details can be found in Ref. 11. The cold-body no-lights/quenched-lights were not attributed to COP failures since video imagery show the RCE core flow ignition, followed by quenching of the jet by the fuel film cooling flow within the jet. However, further testing is needed to verify whether the quenching could have been overcome with an increase in spark energy or increased spark duration (the no-lights/quenched-lights were observed during MIB testing at 40$60 \mathrm{msec})$. 


\section{Summary/Conclusions/Forward Work}

Test results show that coil-on-plug technology offers a viable means of providing spark energy for LOX/LCH4 liquid rocket engine igniters. Table 2 summarizes all the testing conducted using the coil-on-plug igniters for the RCE and main engine igniters in this study at sea-level, vacuum, and thermal-vacuum conditions. It is critically important to note that this study was not intended to be a reliability study. If it had been, orders of magnitude more hot-fire pulses would have been performed and the hardware design and qualification testing would have been more focused on product life. Instead, this study focused on demonstrating that coil-on-plug spark igniter technology could be used at the vehicle level in integrated LOX/LCH4 propulsion systems with acceptable thruster performance and low vehicle electrical impacts. A secondary objective to show that the coil-on-plug technology could be derived from low-cost commercial off-the-shelf sources was also demonstrated.

Table 2. Summary of Successful Hot-Fire Ignition and Coil-on-Plug Failures Observed in Sea-Level Altitude, and Thermal-Vacuum Testing for RCE and Main Engine Igniters

\begin{tabular}{|c|c|c|c|c|}
\hline Test Series & RCE lights & $\begin{array}{l}\mathrm{RCE} C O P \\
\text { failures }\end{array}$ & $\begin{array}{l}\text { ME igniter } \\
\text { lights }\end{array}$ & $\begin{array}{l}\text { ME Igniter } \\
\text { COP failures }\end{array}$ \\
\hline $\begin{array}{l}\text { Component-test, Sea-level } \\
\text { (CryoCart at JSC) }\end{array}$ & 163 & 1 & 10 & 0 \\
\hline $\begin{array}{l}\text { Component-test, Vacuum } 0.02 \text { - } 50 \text { torr } \\
\text { (CryoCart + Vac pipe at JSC) }\end{array}$ & 12 & 0 & 9 & 0 \\
\hline $\begin{array}{l}\text { Integrated Vehicle Test, Sea-level } \\
\text { (at JSC) }\end{array}$ & 88 & 0 & 9 & 2 \\
\hline $\begin{array}{l}\text { Integrated Vehicle test, vacuum } \\
\sim 30 \text { torr (at PB-B2) }\end{array}$ & 959 & $0^{*}$ & 19 & 1 \\
\hline $\begin{array}{l}\text { Integrated Vehicle Test, Thermal- } \\
\text { Vacuum, } 6 \text { torr (at PB-B2) }\end{array}$ & 2 & 1 & Not tested & Not tested \\
\hline
\end{tabular}

Note: * one RCE COP failure was identified during electrical checkouts (i.e., not during hot-fire) and repaired

Future work on the coil-on-plug technology should focus on cold thermal-vacuum testing and hardware reliability. Notably, the spark plug issues encountered on both the RCE and the main engine igniter implementations of the COP can be traced to mechanical hot surface epoxy and ceramic junction hardware development problems, not electrical problems. Additional improvements for hardware reliability are under consideration to address the spark plug portion of the integrated COP.

The thermal-vacuum testing at Plum Brook also identified a key issue that needs further investigation with operating a cryogenic RCS in space conditions; specifically, the no-lights/quenched lights observed in cold-thermal environment testing which needs more testing to resolve the root cause and corrective measures. The thermalvacuum testing portion of this campaign was truncated due to schedule and cost limitations for the overall ICPTA test effort. Modifications to the CryoCart Vacuum Pipe test apparatus at JSC are under consideration to conduct thermal-vacuum ignition testing at the component level.

\section{Acknowledgments}

The coil-on-plug development and JSC testing was funded by the JSC Engineering Directorate, Propulsion and Power Division, Edgar Castro, Chief. ICPTA vehicle development was funded by the JSC Engineering Directorate, Laurie Hansen, Director. Plum Brook Hot-Fire facility testing was funded by the NASA Rocket Propulsion Test Management Board, Roger Simpson, Chair, and Glenn Research Center Plum Brook Propulsion Test Facility, Jerry Hill, Lead. Additional travel required for hot-fire testing at Plum Brook was funded by NASA Advanced Exploration Systems, Jason Crusan, director, and Jon Olansen at JSC.

Mark Lepore of WeaponX, LTD. provided vendor engineering design support for the coil technology development and design.

Patrick McManamen, Bill Studak, Mark Villemarette, Pooja Desai, Jacob Collins, Brian Banker, John Applewhite, Christina Deoja, Bill Holten, Robert Fulmer, Marty Mclean, Mike Reddington, and Josh Sooknanan 
provided propulsion and power engineering at JSC. Additional University of El Paso students Daniela Aguilar, Mariano Mercado, and Pedro Nunez provided test support at JSC and Plum Brook.

Hal Weaver, Brian Jones, John Zang, Nicolas Connelly, Chris Maloney, Wes Sallee, Brad Weisenberger, Jeremiah Folds, Sage Amato, and countless technicians and engineering staff conducted testing at Plum Brook Testing. Ben Stiegemeier of NASA Glenn Research Center and Andrew Guymon of NASA Stennis Space Center provided additional test engineering support.

Integrated ICTPA vehicle testing at JSC was conducted with the efforts of Jim Rice, Ian Young, Jennifer Devolites, Steve Daniel, Jessie Zapata, Fred Shetz, Robert Hirsch, Ronnie Gambrel, Kent Dekome, Dave Swartwout, Randy Wade, and the JSC riggers and technicians.

\section{References}

${ }^{1}$ Smith, T.D., Klem, M.K., and Fisher, K., "Propulsion Risk Reduction Activities for Non-Toxic Cryogenic Propulsion" AIAA-2010-8680, AIAA Space 2010 Conference and Exposition, Anaheim, CA, August 30 - September 2, 2010.

${ }^{2}$ McManamen, J.P., Hurlbert, E.A., and Kroeger, D.J., "Development and Flight Operation of a $5 \mathrm{lbf}$ to 20 lbf O2/CH4 Roll Control Engine for Project Morpheus," AIAA-2014-3589, 50 ${ }^{\text {th }}$ AIAA/ASME/SAE/ASEE Joint Propulsion Conference, Cleveland, OH, July 28-30, 2014.

${ }^{3}$ Kleinhenz, J., Sarmiento, C., and Marshall, W., "Experimental Investigation of Augmented Spark Ignition of a LO2/LCH4 Reaction Control Engine at Altitude Conditions", NASA TM 2012-217611, NASA Glenn Research Center, Cleveland, OH, June, 2012.

${ }^{4}$ Hurlbert, E.A., Angstadt, T., Villamarette, M., Collins, J., Allred, J., Mahoney, J., and Peters, T., "870 lbf Reaction Control System Tests using LOX/Ethanol and LOX/LCH4methane at White Sands Test Facility", AIAA-2008-5247, 44 ${ }^{\text {th }}$ AIAA/ASME/SAE/ASEE Joint Propulsion Conference and Exhibit, Hartford, CT, July 21-23, 2008.

${ }^{5}$ Robinson, P.J., Veith, E.M., Hurlbert, E.A., Jiminez, R., Smith, T.D., "100-lbf LO2/LCH4 Reaction Control Engine Technology Development for Future Space Vehicles" International Astronautical Conference 2008, Glasgow, Scotland, United Kingdom, September 29 - October 3, 2008.

${ }^{6}$ Melcher, J.C., and Allred, J.K., "Liquid Oxygen / Liquid Methane Test Results of the RS-18 Lunar Ascent Engine at Simulated Altitude Conditions at NASA White Sands Test Facility", AIAA-2009-4949, 45 ${ }^{\text {th }}$ AIAA/ASME/SAEE/ASEE Joint Propulsion Conference and Exhibit, Denver, CO, August 2-5, 2009.

${ }^{7}$ Collins, J., Hurlbert, E., Romig, K., Melcher, J., Hobson, A., and Eaton, P., "Sea-Level Flight Demonstration \& Altitude Characterization of a LO2 / LCH4 Based Ascent Propulsion Lander," AIAA-2009-4948, 45 ${ }^{\text {th }}$ AIAA/ASME/SAEE/ASEE Joint Propulsion Conference and Exhibit, Denver, CO, August 2-5, 2009.

${ }^{8}$ Marshall, W. M., and Kleinhenz, J. E., "Analysis of 100-lbf (445-N) LO2-LCH4 Reaction Control Engine Impulse Bit Performance”, NASA TM-2012-217613, NASA Glenn Research Center, Cleveland, OH, June 2012.

9 Marshall, W.M., Osborne, R.J., and Greene, S.E., "Development of Augmented Spark Impinging Igniter System for Methane Engine," AIAA-2017-4665, 2017 AIAA Propulsion and Energy Forum, Atlanta, GA, July 10 -12, 2017.

${ }^{10}$ Morehead, R.L., Melcher, J.C., Atwell, M.J., Hurlbert, E.A., Desai, P., and Werlink, R., "Vehicle-Level Oxygen/Methane Propulsion System Hot-Fire Testing at Thermal Vacuum Conditions," AIAA-2017-4748, 2017 AIAA Propulsion and Energy Forum, Atlanta, GA, July 10 -12, 2017.

${ }^{11}$ Atwell, M.J., Hurlbert, E.A., Morehead, R.L., and Melcher, J.C., "Characterization of Pressure-Fed LOX/LCH4 Reaction Control System Under Simulated Altitude and Thermal Vacuum Conditions," AIAA-2017-4668, 2017 AIAA Propulsion and Energy Forum, Atlanta, GA, July $10-12,2017$. 